\title{
DETERMINATION OF THE FATTY ACID PROFILE IN Eugenia dysenterica DC. SEEDS ${ }^{1}$
}

\author{
YANUZI MARA VARGAS CAMILO², ELI REGINA BARBOZA DE SOUZA ${ }^{3}$, \\ RONALDO VELOSO NAVES ${ }^{3}$, ROSÂNGELA VERA ${ }^{3}$, MUZA DO CARMO VIEIRA ${ }^{4}$
}

\begin{abstract}
The present research aimed to determine the fatty acid profile in the seed oil of cagaita fruits cultivated in Goiânia, state of Goiás, in 2013 and 2014 harvests. The study was carried out with fruits produced by cagaita trees cultivated in the field of the School of Agronomy, Federal University of Goiás (EA/UFG), Goiânia, GO, where, in 1998, 440 cagaita seedlings from different municipalities in Goiás were planted. Fruits were collected from plants with 16 years of age in full production stage. Cagaita seeds show in their fatty acid profile mostly linoleic acid, oleic acid and palmitic acid. There was no variation in fatty acids content present in seeds between years 2013 and 2014, assuming that there are no external influences such as weather, foliar nutrients or soil, in the production of these oils.
\end{abstract}

Index terms: cagaita, native fruit, chemical composition.

\section{DETERMINAÇÃO DO PERFIL DE ÁCIDOS GRAXOS EM SEMENTES DE CAGAITEIRAS (Eugenia dysenterica DC.)}

\begin{abstract}
RESUMO-A presente pesquisa teve como objetivo determinar o perfil de ácidos graxos do óleo de sementes de cagaiteiras cultivadas em Goiânia, no Estado de Goiás, nas safras de 2013 e 2014. O estudo foi desenvolvido com frutos produzidos por cagaiteiras implantadas na área da Escola de Agronomia, da Universidade Federal de Goiás (EA/UFG), em Goiânia, GO, onde, em 1998, foram plantadas 440 mudas de cagaiteiras, oriundas de diferentes municípios do Estado de Goiás. Os frutos foram colhidos em plantas com 16 anos de idade, em plena fase de produção. As sementes de cagaitas apresentam em seu perfil de ácidos graxos, majoritariamente, o ácido linoleico, o ácido oleico e o ácido palmítico. Não houve variação no teor de ácidos graxos presentes nas sementes entre os anos de 2013 e 2014, supondo que não há influências externas, como clima ou nutrientes foliares ou de solo, na produção desses óleos.
\end{abstract}

Termos para indexação: cagaita, fruta nativa, composição química.

\footnotetext{
'(Paper 144-15). Received May 28, 2015. Accepted November 03, 2015. Part of the doctoral thesis of the first author.

${ }^{2} \mathrm{PhD}$ student in Agronomy, School of Agronomy, Federal University of Goiás (EA/UFG), Goiânia-GO, Brazil. Email: yanuzimvc@ gmail.com

${ }^{3}$ Professor at the School of Agronomy, Federal University of Goiás (EA / UFG), Goiânia-GO, Brazil. Email: eliregina1@gmail.com, ronaldo.agro@ufg.br; vera@agro.ufg.br

${ }^{4}$ Agronomist, PhD in Agronomy - Federal Institute of Goiás - Urutaí Campus - Goiás - Brazil. Email: mcvmuza@gmail.com Financial Support: National Council for Scientific and Technological Development - CNPq.
} 


\section{INTRODUCTION}

Cagaita (Eugenia dysenterica DC.), one of the native fruits widely used by the regional population, is one of the species that are suffering with the advancement of agribusiness and the urbanization of the midwestern region of the country. It belongs to the Myrtaceae family, measures on average 4-10 $\mathrm{m}$ in height and occurs naturally in the states of São Paulo, Minas Gerais, Bahia, Tocantins, Mato Grosso, Mato Grosso do Sul, Pará, Maranhão, Piauí and Goiás, as well as in the Federal District (BRITO et al., 2003 ).

The main use of cagaita tree is due to the food potential of its fruits. All fruit production occurs in an extractive way, in natural populations of the species, not being recorded any organized planting initiative (VIEIRA et al., 2010). Its fruits can be consumed fresh, or processed in the form of liqueurs, ice creams, juices or jellies, which constitutes an important source of food and possibility of increase in the income of small farmers of the Brazilian midwestern region (CHAVES; TELLES, 2006). The use of this fruit species can constitute a very promising economic activity, given the excellent quality of its fruits and its most diverse uses (SOUZA et al., 2001).

Thus, cagaita is one of the Cerrado species that have great potential for use in agricultural production systems, presenting high density and good production, which favors the exploitation of native populations in a sustainable way. However, there is still a great shortage in researches to overcome restrictive factors that allow the rational use of the species, requiring more in-depth studies in order to better understand this native fruit (VIEIRA et al., 2010).

A segment still unknown to several native cerrado fruits is the use of their vegetable oils, which represent one of the most important resources provided by nature, being produced and stored in fruits and seeds (ATHAR; NASIR, 2005). Oil extracted from fruit seeds can be used in cosmetics and pharmaceuticals, as edible oil, in varnish industries, etc. Therefore, the development of an effective technological extraction and characterization of its physicochemical composition is of utmost importance (ROY et al., 1996).

Recent studies have shown the influence of environmental variation on chemical constituents, including fat percentage, during the production phase of several plant species. According to Kriskamol et al. (2015), the lipid constituents in black gram seeds (Vigna mungo L.) produced in the dry season were higher than in those produced in the rainy season. The amount of rain, sunlight and temperature also affect the chemical compositions of cloudberry (Rubus chamaemorus L.) (JAKAKOL et al., 2012). This influence could also be observed in oil extracted from rapeseed (Brassica napus L.), with variations of oleic and linoleic acid, according to the production season, spring and winter (RAD, ZANDI, 2012). Since it is not synthesized in the body, these components must be provided through meals, and the extraction of constituents in the time of greater production is of extreme importance.

Thus, the aim of this work was to determine the fatty acid profile of cagaita seeds oil grown in the Cerrado of the state of Goiás in the of 2013 and 2014 harvests, evaluating the effects of climatic conditions on the synthesis of components.

\section{MATERIAL AND METHODS}

Seeds obtained for the research were collected from cagaita trees implanted in the experimental area of the School of Agronomy, Federal University of Goiás (EA / UFG), in Goiânia-GO. Cagaita trees are 16 years old and were implanted in 1998 using seeds collected from cagaita trees in natural environment in 10 municipalities of the state of Goiás. From each locality, 8 to 12 subpopulations were selected, totaling 110 mother plants, which were planted in four blocks, making a total of 440 plants.

From cagaita trees of each block, the maximum number of healthy and good-appearance fruits was collected. Fruits were manually and randomly collected, when fully mature and already fallen to the ground. Collections were carried out in the second fortnight of October 2013 and 2014, season of intense production of fruits.

After pulping, seeds were sent to the Center for Food Research (CPA) of the Veterinary and Animal Science School, Federal University of Goiás (EVZ / UFG) to determine the fatty acid profile according to methodology established by the American Oil Chemists' Society - AOCS (AOCS, 1995).

Data obtained were transformed using the formula $\sqrt{ }$ (value +1 ), according to Volpato and Barreto (2011) in order to obtain greater homogeneity. Subsequently, they were submitted to analysis of variance (ANOVA), and means were compared by the Tukey test at 5\% probability.

Climatic data of temperature (maximum, average and minimum), relative humidity, rainfall and insolation, for the month of October 2013 and 2014, season of cagaita production, were obtained at the First-Class Evaporimetric Station, operating at EA / UFG (Table 1). 
Data analysis was performed using the SAS statistical software (2010).

\section{RESULTS AND DISCUSSION}

Overall, 37 compounds were identified, including saturated, monounsaturated and polyunsaturated fats. Saturated fats accounted for a total of $27 \%$ and unsaturated ones for $73 \%$. Saturated fats presented the highest number of compounds (16); however, when comparing contents, polyunsaturated fats, with 11 compounds, had higher average compared to the others, with $250.036 \mathrm{mg} / 100 \mathrm{~g}$, corresponding to a total of $49.65 \%$. There was no variation of the fatty acid profile in cagaita seeds between years 2013 and 2014 (Table 2).

According to Jorge et al. (2010), the fatty acid composition in cagaita seeds had percentage of $37.66 \%$ of saturated fatty acids, among which palmitic acid, the most prevalent, with an average of $25.12 \%$.

Analyzing the fatty acid profile of jambolan seeds (Syzygium cumini L.), Luzia and Jorge (2009) obtained $67.91 \%$ of the total unsaturated fatty acids, including $24.10 \%$ of monounsaturated fatty acids and $43.81 \%$ of polyunsaturated acids, with linoleic acid being the major component.

In pequi seeds (Caryocar brasilienses), Damiani et al. (2013) found $86.9 \%$ of saturated fatty acids and $10.57 \%$ of unsaturated acids. In pitanga seeds, the same family of cagaita, Luzia et al. (2010) obtained $58.06 \%$ of the total content of unsaturated fatty acids, among which oleic acid, with average of $38.29 \%$, and linoleic acid, with average of $13.46 \%$. The two major acids accounted for $89 \%$ of unsaturated acids, the others appearing in much lower percentages. Among saturated fatty acids, palmitic acid had significant amounts (34.09\%).

Among saturated fats, the acid that presented the highest content in the present study was palmitic acid (C16: 0), with average of $105.990 \mathrm{mg} / 100 \mathrm{~g}$, followed by butyric acid (C4: 0), with $16.701 \mathrm{mg}$ / $100 \mathrm{~g}$, stearic acid (C18: 0), with $7.977 \mathrm{mg} / 100$ $\mathrm{g}$, and arachidic, with $2.004 \mathrm{mg} / 100 \mathrm{~g}$. The others remained with averages ranging from $0.027 \mathrm{mg} / 100$ $\mathrm{g}$ (caproic acid C10: 0) to $0.677 \mathrm{mg} / 100 \mathrm{~g}$ (myristic acid C14: 0) (Table 3). In pequi and pitanga seeds, palmitic acid also stood out with higher amounts when compared to the other acids analyzed (LIMA et al., 2007, DAMIANI et al., 2013). This result is consistent with the fact that palmitic acid is the most abundant saturated fatty acid in plant lipids (JORGE; LUZIA, 2012).

According to Sano and Almeida (1998), palmitic acid is a saturated compound, being the main responsible for the high caloric power. Thus, the consumption of products with high content of this acid provides a feeling of fullness due to its high satiety capacity. However, although saturated, stearic fatty acid is not considered atherogenic since it is rapidly converted into oleic acid (monounsaturated) within the organism, which is beneficial to consumers of foods with higher levels of this compound (CASTRO et al., 2004). Oleic acid is not considered essential and can be synthesized by the human organism from saturated fatty acids (MINAZZIRODRIGUES; PENTEADO, 1991).

Unsaturated fats have positive effects on human health. The consumption of foods with unsaturated fats controls the level of bad cholesterol in the blood and helps to absorb vitamins A, D, E and K (fat soluble vitamins) (HIRAYAMA et al., 2006). Jorge et al. (2010) found in cagaita seeds, amount of unsaturated fatty acids of $62.33 \%$, of which $21.18 \%$ are monounsaturated acids and $41.15 \%$ are polyunsaturated acids, with linoleic acid being the main component. Among monounsaturated and polyunsaturated acids, only oleic acid $(20.17 \%)$ and linoleic acid (38.11\%) were found in significant amounts.

In monounsaturated fat, oleic acid was obtained in high amounts (Table 4), which is vital in the construction of membranes, being present in the epidermis (outermost skin layer), with the function of protection and barrier against dehydration and also in the formation of hormones (HIRAYAMA et al., 2006).

Other authors also report the presence of high content of oleic acid in pequi, pitanga and jambolan seeds (LUZIA, JORGE, 2009; LUZIA et al., 2010; DAMIANI et al., 2013). In baru almonds, the most frequent fatty acids were oleic (45.577-48.985 g / $100 \mathrm{~g})$ and linoleic acids (22.828-29.707 g/ $100 \mathrm{~g})$ (VERA et al, 2009).

In a study carried out by Jardini and ManciniFilho (2007), the fatty acid profile of oil extracted from pomegranate seeds presented high amount of linoleic and oleic acids, accounting for $70.09 \%$ of unsaturated fatty acids, close to values obtained in this study.

In the food industry, oleic acid is the most used in various processes because it provides better quality products. The following are among the various industrial applications: fiber lubricants, hightech lubricants, cosmetics and chemical intermediates (esters, amines, amides). Pequi pulp and baru almond contain high levels of oleic acid (ALMEIDA et al., 2008). 
In polyunsaturated fats, linoleic acid was obtained in greater amount, with $217.164 \mathrm{mg} /$ $100 \mathrm{~g}$, followed by $\alpha$-linolenic acid, with 14.119 $\mathrm{mg} / 100 \mathrm{~g}$ (Table 5). The former is considered an important anti-inflammatory agent, assists in the body defense, improves the immune system and lowers blood cholesterol. The latter is important for the development of the central nervous and visual systems, as it acts on the formation and regeneration of neurons, decreases the risk of cardiovascular diseases, bad cholesterol and blood sugar, being also an anti-inflammatory agent, and its intake is of great importance for humans (HIRAYAMA et al., 2006).

Linoleic acid is abundantly present in plant seeds and in the oils they produce, such as corn, safflower, cotton, soybean and sunflower oil. Linolenic acid, which is also present in some vegetable oils, although to a lesser extent than linoleic acid, is found in chestnuts and linseed (Hirayama et al., 2006).

Although animal tissues can synthesize most saturated and unsaturated fatty acids, they cannot produce unsaturated fatty acids of linoleic series unless a dietary precursor is provided. If linoleic acid is given in the diet, tissues can synthesize the archonic acid from it. This acid, alone or together with linoleic acid, is essential for the maintenance of the normal skin structure (BURTON, 1979).
The quality and digestibility of edible vegetable oils are determined by the amount and composition of unsaturated fatty acids. The presence of linoleic acid in adequate contents is essential, since it is an essential fatty acid. The higher the amount of linoleic acid in relation to oleic acid, the better the quality of vegetable oil in avoiding the formation of bad cholesterol (EL-ADAWY; TAHA, 2001).

Studying the oil obtained from pitanga seeds, Luzia and Jorge (2009) found oleic / linoleic acid ratio (Ole / Lin) of $1 / 0.35$, close to the value found by Borges et al. (2007) for peanut oil ( $1 / 0.5)$. In the present study, this ratio was $1 / 1.9$, evidencing the high amount of oil, which presents higher levels of linoleic acid in relation to oleic acid. This relationship was lower than that obtained by Jorge et al. (2010) in cagaita seeds, with $1 / 1.89$ and higher than that found by Borges et al. (2007) for umbu seeds.

The detailed study of the composition of oil extracted from seeds contributes with professionals of the food area for adequate dietary guidelines, as well as in obtaining data that could be used in composition centesimal tables and of fatty acids and their lipid fraction. Data collection for the composition of Brazilian foods has been stimulated with the objective of obtaining up-to-date, reliable and adequate information to the national reality (LUZIA et al., 2010).

TABLE 1- Mean data of temperature, relative humidity, rainfall and insolation in the region of the School of Agronomy (UFG), Goiânia-GO, in October 2013 and 2014.

\begin{tabular}{|c|c|c|c|c|c|c|}
\hline \multirow{2}{*}{ Month } & \multicolumn{3}{|c|}{ Temperature $\left({ }^{\circ} \mathrm{C}\right)$} & \multirow{2}{*}{ RH\% } & \multirow{2}{*}{ Rainfall (mm) } & \multirow{2}{*}{ Insolation (hour) } \\
\hline & Min. & Interm. & Max. & & & \\
\hline October / 2013 & 19.3 & 25.6 & 32.0 & 55 & 165.5 & 183.6 \\
\hline October / 2014 & 18.1 & 26.1 & 34 & 59 & 53.5 & 218.4 \\
\hline
\end{tabular}

TABLE 2 - Analysis of variance for saturated, monounsaturated and polyunsaturated fats identified in cagaita seeds (Eugenia dysenterica) grown in the experimental area of the School of Agronomy, Federal University of Goiás, Goiânia-GO, harvests of 2013 and 2014.

\begin{tabular}{lccc}
\hline Source of variation & $\begin{array}{c}\text { Saturated Fats } \\
(\mathrm{mg} / 100 \mathrm{~g})\end{array}$ & $\begin{array}{c}\text { Monounsaturated Fats } \\
(\mathrm{mg} / 100 \mathrm{~g})\end{array}$ & $\begin{array}{c}\text { Polyunsaturated Fats } \\
(\mathrm{mg} / 100 \mathrm{~g})\end{array}$ \\
\hline Year & $4.249^{\mathrm{NS}}$ & $2.836^{\mathrm{NS}}$ & $4.814^{\mathrm{NS}}$ \\
Mean & 135.967 & 117.56 & 250.036 \\
VC $\%$ & 28.03 & 51.46 & 53.26 \\
\hline
\end{tabular}

NS - Not Significant. VC - variation coefficient 
TABLE 3- Analysis of variance for the saturated fat content (mg / $100 \mathrm{~g}$ ) present in cagaita seeds (Eugenia dysenterica) grown in the experimental area of the School of Agronomy, Federal University of Goiás, Goiânia-GO, harvests of 2013 and 2014.

\begin{tabular}{|c|c|c|c|c|c|c|}
\hline $\begin{array}{l}\text { Source of } \\
\text { Variation } \\
\end{array}$ & $\begin{array}{c}\text { Butyric acid } \\
\text { C4:0 }\end{array}$ & $\begin{array}{c}\text { Caproic acid } \\
\text { C6:0 }\end{array}$ & $\begin{array}{c}\text { Caprylic acid } \\
\text { C8:0 }\end{array}$ & $\begin{array}{c}\text { Capric acid Hen } \\
\text { C10:0 }\end{array}$ & $\begin{array}{l}\text { ndecanoic acid } \\
\text { C11:0 }\end{array}$ & $\begin{array}{c}\text { Lauric acid } \\
\text { C12:0 } \\
\end{array}$ \\
\hline Year & $7.665^{\mathrm{NS}}$ & $4.832^{\mathrm{NS}}$ & $0.875^{\mathrm{NS}}$ & $1.000^{\mathrm{NS}}$ & $0.673^{\mathrm{NS}}$ & $0,407^{\mathrm{NS}}$ \\
\hline Mean & 16.701 & 0.086 & 0.067 & 0.027 & 0.084 & 0,361 \\
\hline $\mathrm{VC}(\%)$ & 69.35 & 4.99 & 6.49 & 24.80 & 9.51 & 26,57 \\
\hline $\begin{array}{l}\text { Source of } \\
\text { Variation } \\
\end{array}$ & $\begin{array}{l}\text { Myristic Acid I } \\
\text { C14:0 }\end{array}$ & $\begin{array}{l}\text { entadecylic Acid } \\
\text { C15:0 }\end{array}$ & $\begin{array}{c}\text { Palmitic Acid } \\
\text { C16:0 }\end{array}$ & $\begin{array}{c}\text { Margaric } \\
\text { Acid C17:0 } \\
\end{array}$ & $\begin{array}{c}\text { Stearic acid } \\
\text { C18:0 } \\
\end{array}$ & \\
\hline Year & $2.142^{\mathrm{NS}}$ & $0.835^{\mathrm{NS}}$ & $8.297^{\mathrm{NS}}$ & $1.170^{\mathrm{NS}}$ & $7.421^{\mathrm{NS}}$ & \\
\hline Mean & 0.677 & 0.126 & 105.990 & 0.213 & 7.977 & \\
\hline $\mathrm{VC}(\%)$ & 19.27 & 6.21 & 32.06 & 6.22 & 22.87 & \\
\hline $\begin{array}{l}\text { Source of } \\
\text { Variation } \\
\end{array}$ & $\begin{array}{l}\text { Arachidonic } \\
\text { Acid C20:0 }\end{array}$ & $\begin{array}{c}\text { Heneicosanoic } \\
\text { Acid C21:0 }\end{array}$ & $\begin{array}{c}\text { Behenic acid } \\
\text { C22:0 }\end{array}$ & $\begin{array}{c}\text { Tricosanoic acid } \\
\text { C23:0 }\end{array}$ & \multicolumn{2}{|c|}{$\begin{array}{c}\text { Lignoceric acid } \\
\text { C24:0 } \\
\end{array}$} \\
\hline Year & $6.431^{\mathrm{NS}}$ & $1.818^{\mathrm{NS}}$ & $0.128^{\mathrm{NS}}$ & $0.822^{\mathrm{NS}}$ & \multicolumn{2}{|r|}{$0.029^{\mathrm{NS}}$} \\
\hline Mean & 2.004 & 0.394 & 0.436 & 0.411 & \multicolumn{2}{|c|}{0.413} \\
\hline $\mathrm{VC}(\%)$ & 33.15 & 17.43 & 15.39 & \multicolumn{3}{|c|}{25.60} \\
\hline
\end{tabular}

NS - Not Significant. VC - variation coefficient

TABLE 4- Analysis of variance for monounsaturated fats (mg / $100 \mathrm{~g}$ ), present in cagaita seeds (Eugenia dysenterica) grown in the experimental area of the School of Agronomy, Federal University of Goiás, Goiânia-GO, harvests of 2013 and 2014.

\begin{tabular}{lccccc}
\hline $\begin{array}{l}\text { Source of } \\
\text { Variation }\end{array}$ & $\begin{array}{c}\text { Myristoleic Acid } \\
\text { C14:1 N5 }\end{array}$ & C 15:1 N3 & $\begin{array}{c}\text { Palmitoleic acid } \\
\text { C16:1N9 }\end{array}$ & $\begin{array}{c}\text { Palmitoleate acid } \\
\text { C16:1 N7 }\end{array}$ & C17:1 N7 \\
\hline Year & $2.359^{\mathrm{NS}}$ & $2.882^{\mathrm{NS}}$ & $2.092^{\mathrm{NS}}$ & $4.351^{\mathrm{NS}}$ & $0.587^{\mathrm{NS}}$ \\
Mean & 0.005 & 0.012 & 0.870 & 0.081 & 1.084 \\
VC $(\%)$ & 0.44 & 1.01 & 20.30 & 4.98 & 53.64 \\
\hline $\begin{array}{l}\text { Source of } \\
\text { Variation }\end{array}$ & Oleic Acid & $\mathrm{C} 20: 1 \mathrm{~N} 9$ & $\mathrm{C} 22: 1 \mathrm{~N} 9$ & $\begin{array}{c}\text { Nervonic acid } \\
\text { C24:1 N9 }\end{array}$ \\
\hline Year & $0.347^{\mathrm{NS}}$ & $0.697^{\mathrm{NS}}$ & $0.041^{\mathrm{NS}}$ & $2.010^{\mathrm{NS}}$ & \\
Mean & 113.057 & 2.156 & 0.005 & 0.290 & \\
VC $(\%)$ & 86.62 & 70.60 & 0.35 & 15.00 & \\
\hline
\end{tabular}


TABLE 5 - Analysis of variance for the polyunsaturated fats content (mg / $100 \mathrm{~g})$, present in cagaita seeds (Eugenia dysenterica) grown in the experimental area of the School of Agronomy, Federal University of Goiás, Goiânia-GO, harvests of 2013 and 2014.

\begin{tabular}{|c|c|c|c|c|}
\hline \multirow{2}{*}{$\begin{array}{l}\text { Source of } \\
\text { Variation }\end{array}$} & \multirow{2}{*}{$\begin{array}{l}\text { Linoleic Acid } \\
\text { C18:2 N6 }\end{array}$} & \multirow{2}{*}{$\begin{array}{l}\text { Linolelaidic acid } \\
\text { C18:2N6 trans }\end{array}$} & \multicolumn{2}{|c|}{$\alpha$-Linolenic acid C18:3 $\gamma$-linolenic acid C18:3 } \\
\hline & & & N3 & N6 \\
\hline Year & $5.626^{\mathrm{NS}}$ & $0.859^{\mathrm{NS}}$ & $0.797^{\mathrm{NS}}$ & $0.127^{\mathrm{NS}}$ \\
\hline Mean & 217.164 & 0.958 & 14.119 & 0.759 \\
\hline VC $(\%)$ & 49.39 & 50.61 & 54.77 & 56.17 \\
\hline $\begin{array}{l}\text { Source of } \\
\text { Variation }\end{array}$ & $\mathrm{C} 20: 2$ & $\begin{array}{c}\text { Dihomo- }(\alpha) \text { linolenic acid } \\
\text { C20:3 N3 }\end{array}$ & $\begin{array}{l}\text { Dihomo- } \gamma \text {-linolenic } \\
\text { acid C20:3 N6 }\end{array}$ & $\begin{array}{l}\text { Arachidonic acid } \\
\text { C20:4 N6 }\end{array}$ \\
\hline Year & $0.003^{\mathrm{NS}}$ & $1.000^{\mathrm{NS}}$ & $2.291^{\mathrm{NS}}$ & $3.963^{\mathrm{NS}}$ \\
\hline Mean & 0.252 & 0.009 & 0.366 & 0.158 \\
\hline $\mathrm{VC}(\%)$ & 7.23 & 0.49 & 26.67 & 8.92 \\
\hline $\begin{array}{l}\text { Source of } \\
\text { Variation }\end{array}$ & C20:4 N9 & $\mathrm{C} 22: 2 \mathrm{~N} 6$ & $\begin{array}{c}\text { DHA } \\
\text { C22:6 N3 }\end{array}$ & \\
\hline Year & $1.485^{\mathrm{NS}}$ & $1.684^{\mathrm{NS}}$ & $0.949^{\mathrm{NS}}$ & \\
\hline Mean & 5.870 & 0.012 & 10.369 & \\
\hline $\mathrm{VC}(\%)$ & 160.56 & 1.30 & 139.06 & \\
\hline
\end{tabular}

\section{CONCLUSIONS}

Cagaita seeds presented in their fatty acid profile $73 \%$ of unsaturated fats and $27 \%$ of saturated fats.

The major fatty acids present in the seeds were linoleic acid, oleic acid and palmitic acid.

There was no variation in the fatty acid composition present in seeds between years 2013 and 2014, therefore concluding that there are no external influences such as climate or foliar or soil nutrients in the production of these oils.

\section{REFERENCES}

ALMEIDA, S.P.; COSTA, T.S.A.; SILVA, J.A. Frutas nativas do Cerrado: caracterização físico-química e fonte potencial de nutrientes In: SANO, M.S.; ALMEIDA, S.P.; RIBEIRO, J.F. (Ed.). Cerrado: ecologia e flora. Brasília: Embrapa Informação Tecnológica, 2008. p.353-381.

AOAC - Association of Official Analytical Chemists. Official methods of analysis of the Association of Official Analysis Chemists. Arlington, 1995. p.957.
ATHAR, M.; NASIR, M. Taxonomic perspective of plant species yielding vegetable oils used in cosmetics and skin care products. African Journal of Biotechnology, Nairobi, v.4, p.36-44, 2005.

BORGES, S.V.; MAIA, M.C.A.; GOMES, R.C.M.; CAVALCANTI, N.B. Chemical composition of umbu (Spondias tuberosa Arr. Cam) seeds. Quimica Nova, São Paulo, v.30, n.1, p.49-52, 2007.

BRITO, M.A.; PEREIRA, E.B.C.; PEREIRA, A.V.; RIBEIRO, J.F.R. Cagaita: biologia e manejo. Brasília, DF: Embrapa Cerrados, 2003. 80 p.

BURTON, B.J. Nutrição humana. São Paulo: McGraw-Hill do Brasil, 1979.

CASTRO, H.F.; MENDES, A.A.; SANTOS, J.C.; AGUIAR, C.L. Modificação de óleos e gorduras por biotransformação. Química Nova, São Paulo, v.27, n.1, p.146-156, 2004.

CHAVES, L.J.; TELLES, M.P.C. Cagaita. In: VIEIRA, R.F.; COSTA, T.S.A.; SILVA, D.B.; FERREIRA, F.R.; SANO, S.M. (Ed.). Frutas nativas da região Centro-Oeste do Brasil. Brasília: Embrapa Recursos Genéticos e Biotecnologia, 2006. cap.7, p.120-134. 
DAMIANI, C.; ALMEIDA, T.L.; COSTA, N.; MEDEIROS, N.; SILVA, A.G.D.M.; SILVA, F.A.; LAGE, M.E.; BECKER, F.S. Perfil de ácidos graxos e fatores antinutricionais de amêndoas de pequi crua e torrada. Pesquisa Agropecuária Tropical, Goiânia, v.43, n.1, p.71-78, 2013.

EL-ADAWY, T.A.; TAHA, K.M. Characteristics and composition of different seed oils and flours. Food Chemistry, London, v.74, n.1, p.47-54, 2001.

HIRAYAMA, K.B.; SPERIDIÃO, P.G.L.; FAGUNDES NETO, U. Ácidos graxos poliinsaturados de cadeia longa. 2006, v.10. Disponível em: $<\underline{\text { http: } / /}$ www.e-gastroped.com.br/sep06/acidosgraxos.htm $>$. Acesso em: dez. 2014.

JAAKKOLA, M.; KORPELAINEN, V.; HOPPULA, K.; VIRTANEN, V. Chemical composition of ripe fruits of Rubus chamaemorus L. grown in different habitats. Journal of Science and Food Agriclture, Chichester, v.92, p.1324-1330, 2012.

JARDINI, F.A.; MANCINI-FILHO, J. Composição centesimal e perfil dos ácidos graxos da romã (Punica granatum L.) cultivada no Brasil. Higiene Alimentar, São Paulo, v.21, n.148, p.81-85, 2007.

JORGE, N.; LUZIA, D. M. M.; BERTANHA, B. J. Eugenia dysenterica DC.: actividad antioxidante, perfil de ácidos grasos y determinación de tocoferoles. Revista Chilena de Nutrición, Santiago, v.37, n.2, p.208-2014, 2010.

JORGE, N.; LUZIA, D.M.M. Caracterização do óleo das sementes de Pachira aquatica Aublet para aproveitamento alimentar. Acta Amazonica, Manaus, v.42, n.1, p.149-156, 2012.

KRISKAMOL, N.J.; WASAPORN, C.; SUMANA N.Effect of genetic and climatic variability on the metabolic profiles of black gram(Vigna mungo L.) seeds and sprouts. Journal of Science and Food Agriclture, Chichester, v.95, p.1662-1669, 2015.

LIMA, A.; SILVA, A. M. D. O.; TRINDADE, R. A.; TORRES, R. P.; MANCINI-FILHO, J. Composição química e compostos bioativos presentes na polpa e na amêndoa de pequi (Caryocar brasiliense Camb). Revista Brasileira de Fruticultura, Jaboticabal, v.29, n.3, p.695-698, 2007.
LUZIA, D.M.M.; BERTANHA, B.J.B.; JORGE, N. Sementes de pitanga (Eugenia uniflora L.): potencial antioxidante e perfil de ácidos graxos. Revista do Instituto Adolfo Lutz, São Paulo, v.69, n.2, p.175$180,2010$.

LUZIA, D.M.M.; JORGE, N.Composição centesimal, potencial antioxidante e perfil dos ácidos graxos de sementes de jambolão (Syzygium cumini L.). Revista Ciência Agronômica, Fortaleza, v.40, n.2, p.219223, 2009.

MINAZZI-RODRIGUES, S.R.; PENTEADO, C.V.M. Importância do óleos de peixe em nutrição e fisiologia humana. Cadernos de Nutrição, Ribeirão Preto, v.3, p.41-97, 1991.

RAD, A.H.S.; ZANDI, P.A comparison of fatty acid compounds in winter and spring rapeseed varieties. Annals of Biological Research, Uadipor, v.3, n.3, p.1408-1414, 2012.

ROY, B. C.; GOTO, M.; HIROSE, T. Temperature and pressure effects on supercritical $\mathrm{CO} 2$ extraction of tomato seed oil. Journal of Food Science and Technology, Mysore, v.31, p.137-141, 1996.

SANO, M. S.; ALMEIDA, S. P.Cerrado: ambiente e flora. Planatina: Embrapa-CPAC, 1998. 556 p.

SAS INSTITUTE. SAS User's Guide. Cary, 2010.

SOUZA, E.R.B.; CARNEIRO, I.F.; NAVES, R.V.; BORGES, J.D.; LEANDRO, W.M.; CHAVES, L.J. Emergência e crescimento de cagaita (Eugenia dysenterica DC.) em função do tipo e do volume de substratos. Pesquisa Agropecuária Tropical, Goiânia, v.31, n.2, p.89-95, 2001.

VERA, R.; SOARES JÚNIOR, M.S.; NAVES, R.V.; SOUZA, E.R.B.; FERNANDES, E.P.; CALIARI, M.; LEANDRO, W.M. Caracterização física e química de amêndoas de barueiros (Dipteryx alata Vog.) de ocorrência natural no Cerrado do Estado de Goiás, Brasil. Revista Brasileira de Fruticultura, Jaboticabal, v.31, n.1, p.112-118, 2009.

VIEIRA, R.F.; AGOSTINI-COSTA, T.D.S.; SILVA, D.B.; SANO, S.M.; FERREIRA, F.R. Frutas nativas da região centro-oeste do Brasil. Brasília, DF: Embrapa Informações Tecnológicas, 2010. 322 p.VOLPATO, G. L.; BARRETO, R. E. Estatística sem dor. Botucatu: Best Wrinting, 2011. 64 p. 
